\title{
Tax Evasion and its Effects on the Economy
}

\author{
Madhav Khanal, M. Phil. \\ Lecturer \\ Department of Education and Social Science \\ Janamaitri Multiple Campus, Kuleshwar, Kathmandu, Nepal \\ Email:madhavakhanal@gmail.com
}

\begin{abstract}
Tax evasion happens when individuals, organization or agency purposely do not adhere to their tax obligation. The loss of tax revenue caused by tax evasion seriously hampers the proper functioning of the public sector by creating problems in its ability to finance its expenses. The study investigates the opinion of the tax professionals regarding the tax evasion in Nepal with the focus on the factors responsible for the tax evasion and possible remedies to decrease the problem of tax evasion. The main objective of the study is to identify the causes of income tax evasion and assess the impact of tax evasion in Neal. To collect the information regarding tax evasion in Nepal a well-designed questionnaire with five-point Likert scale has been used. Their opinion reveals that high tax rates, corruption in public sector units, multiple tax rates and inefficient tax authorities are the main causes of tax evasion in Nepal.
\end{abstract}

Keywords: Tax evasion, Tax Avoid, Tax Haven, Corruption, Tax rate.

\section{Introduction}

Tax evasion is a challenging issue, in most countries, to the tax authorities and has been in existence for a long time. Scholars have defined and explained tax evasion in different ways. It has been discussed in a variety of disciplines including accounting, economics, psychology, political science, law and sociology. (Webley et al., 1991).

In Nepal, most people do not pay their taxes (Kemal, 2007 \& Gupta, 1992). They try to avoid tax by some illegal means or by taking the benefit of some loopholes that exist in the Nepalese tax system. Tax evasion is the illegal act of not paying the taxes that one owes. Tax evasion is different from tax minimization/avoidance, which is the legal act of using every tax law and loophole available to minimize the amount of taxes owing. 
Akdede (2006) has defined tax evasion as an illegal act to avoid paying taxes by violating tax laws. He further argues that people naturally seek not to pay taxes if they can find any way to do so. According to Sandmo (2005), tax evasion refers to the violation of laws by a taxpayer through escaping his taxable income obligations to the relevant authority.

\section{Statement of the Problem}

The problem of tax evasion is a complex multidimensional problem. There are many different reasons why people and companies try to avoid reducing the amount of taxes they have to pay for semi-legal or illegal practices.

There are several reasons for tax evasion and tax avoidance. In order to develop methods and tools to combat tax evasion and tax avoidance, it is important that the majority establish a broad understanding of the various reasons behind these problems. These reasons can be filed in two categories. The first category includes factors that adversely affect taxpayers' compliance with tax legislation. They can be summarized both by contributing to a low willingness to pay taxes (low fiscal morals) and high costs to comply with tax laws. The second category contains reasons for the limited capacity of the tax administration and tax courts to enforce tax obligations. These factors can be summarized as a consequence of inadequate administration and tax collection, as well as the limited ability to monitor and monitor tax payments, which limits the possibility of identifying and prosecuting offenders.

In Nepal, Tax Revenue - GDP Ratio is only $23.8 \%$ in country's gross domestic product and Income tax to GDP 5.7\%. This clearly indicates a narrow tax base. Less than 5\% of the total population in Nepal pays taxes. There are a large number of hard to tax groups like small businesses, small farms and professionals. Tendency to deliberately remain outside the tax threshold is predominant. The low number of tax assessment in comparison to the number of registered taxpayers indicates inefficiency of administration. The weak tax collection is also associated with low tax payer morale, corruption and weak governance. The low level of trust among tax payers and tax authority has weakened the tax administration of Nepal making it harder to comply with tax laws. The contribution of income tax in comparison to GDP Bangladesh, 2.7\%, India 2.0\%, Afghanistan below $1 \%$ and Nepal $5.7 \%$. The contribution of income tax in comparison to GDP Bangladesh, $2.7 \%$, India $2.0 \%$, Afghanistan below $1 \%$ and Nepal 5.7\%.

Following the adoption of various tax policies in Nepal, operations of traders in Kathmandu have seen a stressful transformation. It is an open truth that the traders in the informal sector have not been paying taxes and are not eager to do so.

It is upon observation made by the various studies and government officials that the researchers embarked on this research study as a way of investigating the reasons for evasion of the payment of income taxes by the traders and its effects on the economy. 


\section{The objective of the study}

The objectives of the study are:

- To examine why people evade income tax payment,

- To examine the effect of income tax evasion on the economy.

\section{Significance of the study}

The study is helpful for traders, tax administrators and other stakeholders; it informs about the impact taxes and its scheme has on developing a nation by government.

Policy makers would have the advantage of improving strategies and laws for administering tax on traders in Nepal from the findings and conclusions drawn out from the research. Other researchers interested in the same study area can refer to for further projects.

\section{Limitations/scope of the study}

Traders in Kathmandu are mostly self-employed in the informal sector; this, as a result, made it difficult to access some vital information even though their confidentiality was assured.

\section{Literature Review}

Kemal (2007) suggests that income from illegal activities which remain out of the tax net, including smuggling, corruption, black-marketing, narcotics, and informal jobs, constitute an 'underground economy'. According to Gupta (1992), 'black income', commonly known as 'black money', involves not disclosing the source of income and does not enter into books of account in order to avoid or evade tax payment. The forms and sources of black income are not only limited to tax evasion, but also include crime income, bribe income, black-market income, black-wealth income, smuggling income, and income generated from leakages of government expenditure, and so on. Black income can be of two types: unrepeatable and reportable. Unrepeatable black income cannot be reported to income tax authority because it is earned through illegitimate and illegal means. Reportable black income, on the other hand, is earned legitimately, however is concealed as income from the tax department (Gupta, 1992).

The theoretical literature on tax evasion is based on seminal work of Allingham and Sandmo (1972), which in turn is based on Becker's (1968) economic approach to crime.

They analyzed the evasion decision of an individual as a choice under uncertainty. They were interested in studying the effect of the tax rate, taxpayer's income, and enforcement parameters on the level of tax evasion.

However, Allingham and Sandmo showed that the effect of the taxpayer's before tax income on the proportion of income unreported depends only on the relative risk aversion of the taxpayer's utility function. Thus, when actual income varies, the fraction of income not declared decreases (increases) if the relative risk aversions are an increasing (decreasing) function of income. 
Regarding the relationship between the tax rate and the amount of income unreported, a notable feature of the Allingham and Sandmo model is that it lends an ambiguous result. Under the plausible assumption of decreasing absolute risk aversion, Allingham and Sandmo showed that the substitution and income effects of the change in the tax rate conflict each other resulting in an ambiguous overall effect. Yitzhaki (1974) resolves this ambiguity. By assuming that the penalty rate is imposed on the evaded tax rather than on the unreported income, he shows that there is no substitution effect of the change in tax rate and the remaining income effect implies that, as the tax rate increases, the amount of income unreported decreases. Although, the Yitzhaki model resolves the ambiguity of the Allingham and Sandmo model regarding the effects of the tax rate on the extent of tax evasion, its conclusion is against the commonly held view that a higher tax rate increases tax evasion.

There are few theoretical models that relate tax evasion to macroeconomic factors. Fishburn (1981) analyzes the effect of inflation on the level of tax evasion. One-way inflation can affect the decision to evade taxes is by eroding the real value of a given level of nominal disposable income. This provides an incentive for the taxpayer to restore his purchasing power through evasion. Fishburn's results show that a risk-neutral individual's evasion decision is independent of the price level, while that of a risk-averse individual depends on the properties of the relative risk-aversion function. In particular, the observed proportion of true income unreported by a risk-averse individual is a nondecreasing (none increasing) function of the price level if relative risk aversion is an increasing (decreasing) function of income. Another way inflation can affect tax evasion is through tax bracket creep. Since most tax systems are not indexed, higher inflation pushes taxpayers into higher tax brackets even though their income is adjusted with costof-living index changes.

Studies in the U.S. by Etzioni (1986), addressed the debate as to whether tax evasion results from increased tax rates and economic incentives as claimed by several scholars. Using survey data collected between 1960 and 1980, the author found that tax evasion increased during the periods as most Americans considered taxes as unfair even though tax rates remained stable. The information gathered in the survey led the author to conclude that the growing sense that taxes are unfair is more likely than increasing tax rates and one's level of income to lead to tax evasion. This position was corroborated by Fisman and Wei (2003) when they examined tax evasion in China by comparing the values of the country's imports from

Hong-Kong, with what Hong-Kong reported as exports to china over a defined period. The result was that on average, $1 \%$ increase in tax rate is accompanied by a $3 \%$ escalation in evasion. However, there was a non-linear correlation as evasion elasticity is larger at higher tax levels. In a related study, Levin and Widell (2007) estimated the amount of tax evasion in customs authorities in Kenya and Tanzania by calculating measurement errors 
with tax rates through evidence from missing imports. Findings concluded that coefficient on tax is higher in Tanzania as compared to

Kenya, implying that tax evasion on imported goods is higher in Tanzania than Kenya and ultimately tax evasion is more severe in the Tanzanian customs authority. Ultimately, corruption amongst tax officials and lack of transparency in tax revenue accountability are responsible for tax evasion in these countries.

A study of tax evasion in Armenia (McGee, 1999 b) found the two main reasons for evasion to be the lack of a mechanism in place to collect taxes and the widespread opinion that the government does not deserve a portion of a worker's income.

Robert W. McGee's The Ethics of Tax Evasion Perspectives in Theory and Practice Springer New York Dordrecht Heidelberg London 2012 presents four Views on the Ethics of Tax Evasion-

- View One: Tax Evasion Is Never Ethical

- View Two: Tax Evasion Is Always Ethical

- View Three: Tax Evasion Is Sometimes Ethical

- View Four: There Is an Affirmative Duty to Evade Taxes

The first view takes the position that tax evasion is always, or almost always unethical. There are basically three underlying rationales for this belief. One reason is the belief that individuals have a duty to the state to pay whatever taxes the state demands. This view is especially prevalent in democracies, where there is a strong belief that individuals should conform to majority rule. The second rationale for an ethical duty to pay taxes is because the individual has a duty to other members of the community. This view holds that individuals should not be freeloaders by taking advantage of the services the state provides while not contributing to the payment of those services. A corollary of this belief is the view that if tax dodgers do not pay their fair share, then law-abiding taxpayers must pay more than their fair share. The third rationale is that we owe a duty to God to pay taxes, or, stated differently, God has commanded us to pay our taxes. This view holds no water among atheists, of course, but the view is strongly held in some religious circles.

Second view might be labeled the anarchist view. This view holds that there is never any duty to pay taxes because the state is illegitimate, a mere thief that has no moral authority to take anything from anyone. The state is no more than a mafia that, under democracy, has its leaders chosen by the people. The anarchist literature does not address the ethics of tax evasion directly but rather discusses the relationship of the individual to the state. The issue of tax evasion is merely one aspect of that relationship. There is no such thing as a social contract according to this position. Where there is no explicit agreement to pay taxes there also is no duty. All taxation necessarily involves the taking of property by force or the threat of force, without the owner's permission. Thus, it meets the definition of theft. Stated as an equation, "TAXATION $=$ THEFT". A corollary equation is that FAIR SHARE $=0$. 
Third view holds that tax evasion may be ethical under some circumstances and unethical under other circumstances. This view is that there is some duty to pay, but the duty is less than absolute.

Fourth view is that there can be an affirmative duty not to pay. At least three arguments can be put forth to justify this position - the state is evil or corrupt, and thus is not entitled to receive the fruits of our labor; evading taxes is a positive-sum game, because the private sector is more efficient than the government sector; and tax evasion results in a more just society because there are fewer property rights violations if taxes are evaded.

In addition, Wallschutzky's empirical research (1984) has identified a number of possible causes that inspire taxpayers to evade tax, including high tax rates, a government's unwise use of tax money, rich people's tax avoidance and inequity in the tax system. Alm, McClelland and Schulze (1992) argue that detection and punishment alone cannot influence taxpayers' decisions between compliance or non-compliance; rather, a number of other variables play an important role. As they (1992: 36) say:

An increase in the amount that individuals receive from a given tax payment increases their compliance rate, and individuals pay something in taxes to receive government services even when there is no chance of detection and punishment.

\section{Research Design}

The study was designed to delve into the causes of income tax evasion and the consequent effects of such evasion on the economy. For the purpose of convenience, Kathmandu was taken as a study area. Traders based on Kathmandu will be selected for the case study.

\section{Population and sample}

Population is the whole size of study covering all the population while taking data; the study reveals more accurate findings. It is not possible due to various constraints likes as time value of money etc. so this study took sample from large population. Traders in Kathmandu Valley are total population. The study took 30 traders using Judgmental sampling method as the representative respondents from various businesses.

\section{Data Collection Techniques}

Data is the foundation of all the research. Research is the systematic study of the certain specific problem. That is why the study requires adequate relevant qualitative and quantitative information. Data collection is the most essential aspect of any research because the whole result of research depends on the adequacy and relevancy of the data. This study was based on the primary and secondary data.

\section{Primary Data}

To collect primary data, questionnaires was the major instruments used in the data collection for the study. The questionnaires were afforded and the opportunity to obtain 
frank answers to sensitive and relevant questions as the respondents felt at ease when providing answers to them. Interviews will also be employed to an appreciable extent.

\section{Questionnaires}

The questionnaires were designed in such a way that names of respondents is not required; the only thing needed from them was the expression of their candid opinion on the issues raised to make our informed judgments. In the quest of this, two well-structured sets of questionnaires were designed; one for traders who form the core group of the study. Causes of refuse to pay tax and impact of income tax evasion are measure 5-point Likert scale.

\section{Interviews}

An interview schedule was prepared to collect the views of income tax evasion. Some of the respondents to whom the questionnaires were forwarded could not read and write, as a result and they were not in the position to answer by themselves.

\section{Secondary Data}

Secondary data was collected from following sources:

- Published and unpublished reports, articles and dissertation on the concerned subject.

- Publication of economic survey in various Fiscal Years of MOF/Nepal.

- Related articles and journals.

- Daily, weekly and monthly newspapers and magazines, which are related to the research.

- Different relevant websites.

- Validity and reliability

The anonymity of the study makes it possible for generating reliable responses, which have been considered accurate enough to make the study dependable.

\section{Data Analyses and Presentation}

The overall data collected have been analyzed by the use of frequency tables, percentages and bar charts as per need.

\section{Why Do People Evade Income Tax Payment?}

According to Tom Cardamone, the director of Global Financial Integrity, "people see tax as a cost. It's not; it's an investment. It goes into government coffers to improve infrastructure, healthcare, etc. This is the fundamental problem in how people view tax" (Law Review, 2012).

One of the causes of avid seeking of loopholes and consequent tax avoidance behavior may be high tax rates. "There are many reasons why tax avoidance and tax evasion take place, including high tax rates, imprecise laws and lack of deterrents. With higher tax 
rates, organizations or individuals may find it worthwhile to spend more time and money on advice, perform more complex maneuvers and take greater risks, in order to avoid or evade tax liabilities" (Stainer et al., 1997).

Table 1: Causes of Refuse to Pay Tax Intentionally

\begin{tabular}{|c|c|c|c|c|c|c|}
\hline Impact & Category & Frequency & Percent & $\begin{array}{c}\text { Cumulative } \\
\text { Percent }\end{array}$ & Mean & $\begin{array}{c}\text { Std. } \\
\text { Deviation }\end{array}$ \\
\hline \multirow{6}{*}{$\begin{array}{l}\text { High Tax } \\
\text { Rates }\end{array}$} & Strongly disagree & 0 & 0 & 0 & \multirow[b]{6}{*}{3.7} & \multirow[b]{6}{*}{1.074} \\
\hline & Disagree & 7 & 23.3 & 23.3 & & \\
\hline & $\begin{array}{l}\text { Neither agree nor } \\
\text { disagree neither }\end{array}$ & 8 & 26.7 & 50 & & \\
\hline & Agree & 9 & 30 & 80 & & \\
\hline & Strongly agree & 6 & 20 & 100 & & \\
\hline & Total & 30 & 100 & & & \\
\hline \multirow{6}{*}{$\begin{array}{l}\text { Complex tax } \\
\text { system }\end{array}$} & Strongly disagree & 0 & 0 & 0 & & \multirow[b]{6}{*}{0.809} \\
\hline & Disagree & 10 & 33.3 & 33.3 & & \\
\hline & $\begin{array}{l}\text { Neither agree nor } \\
\text { disagree neither }\end{array}$ & 11 & 36.7 & 70 & & \\
\hline & Agree & 9 & 30 & 100 & & \\
\hline & Strongly agree & 0 & 0 & 100 & & \\
\hline & Total & 30 & 100 & & 2.97 & \\
\hline \multirow{6}{*}{$\begin{array}{l}\text { Inefficient tax } \\
\text { authorities }\end{array}$} & Strongly disagree & 7 & 23.3 & 23.3 & & \multirow[b]{6}{*}{0.868} \\
\hline & Disagree & 11 & 36.7 & 60 & & \\
\hline & $\begin{array}{l}\text { Neither agree nor } \\
\text { disagree neither }\end{array}$ & 8 & 26.7 & 86.7 & & \\
\hline & Agree & 3 & 10 & 96.7 & & \\
\hline & Strongly agree & 1 & 3.3 & 100 & & \\
\hline & Total & 30 & 100 & & 2.33 & \\
\hline \multirow{6}{*}{$\begin{array}{c}\text { Ineffective } \\
\text { enforcement } \\
\text { of law }\end{array}$} & Strongly disagree & 7 & 23.3 & 23.3 & \multirow[b]{6}{*}{2.57} & \multirow[b]{6}{*}{1.104} \\
\hline & Disagree & 6 & 20 & 43.3 & & \\
\hline & $\begin{array}{l}\text { Neither agree nor } \\
\text { disagree neither }\end{array}$ & 10 & 33.3 & 76.7 & & \\
\hline & Agree & 7 & 23.3 & 100 & & \\
\hline & Strongly agree & 0 & 0 & & & \\
\hline & Total & 30 & 100 & & & \\
\hline
\end{tabular}




\begin{tabular}{|c|c|c|c|c|c|c|}
\hline \multirow{6}{*}{$\begin{array}{l}\text { Low tax } \\
\text { morality }\end{array}$} & Strongly disagree & 0 & 0 & 0 & \multirow[b]{6}{*}{3.97} & \multirow[b]{6}{*}{0.999} \\
\hline & Disagree & 3 & 10 & 10 & & \\
\hline & $\begin{array}{l}\text { Neither agree nor } \\
\text { disagree neither }\end{array}$ & 6 & 20 & 30 & & \\
\hline & Agree & 10 & 33.3 & 63.3 & & \\
\hline & Strongly agree & 11 & 36.7 & 100 & & \\
\hline & Total & 30 & 100 & & & \\
\hline \multirow{6}{*}{$\begin{array}{l}\text { No any d irect } \\
\text { or indirect } \\
\text { benefit }\end{array}$} & Strongly disagree & 0 & 0 & 0 & \multirow[b]{6}{*}{4.37} & \multirow[b]{6}{*}{0.765} \\
\hline & Disagree & 0 & 0 & 0 & & \\
\hline & $\begin{array}{l}\text { Neither agree nor } \\
\text { disagree neither }\end{array}$ & 5 & 16.7 & 16.7 & & \\
\hline & Agree & 9 & 30 & 46.7 & & \\
\hline & Strongly agree & 16 & 53.3 & 100 & & \\
\hline & Total & 30 & 100 & & & \\
\hline
\end{tabular}

Source: Field survey, 2016

Table 1 shows the responses given by the main causes of evade paying income tax on a five-point scale. Table 1 depicts the main causes of refuse to pay tax intentionally given by the tax traders. Majority of the respondents identified that no any direct benefit to pay tax (mean score 4.37) 83.3\%, Low tax morality (mean score 3.97) 70\%, High Tax Rates (mean score 3.7)56.7\%. Beside this complex tax system (mean score 2.97) 30\%, Ineffective enforcement of law (mean score 2.57) $23.3 \%$, and Inefficient tax authorities (mean score 2.33) 13\%, are the other causes of refuse to pay tax intentionally.

\section{Effects of Income Tax Evasion on The Economy}

Revenues generated from taxes constitute a major source of income for governments.

Fuest C, Riedel N.(2009)Tax revenues for financing public services and infrastructure are a key factor for economic growth and development. In recent times, emerging economies fail to generate the required tax revenues to finance expenditures.

The classical view is that the increase in the tax rates will lead to an increase in the size of the underground economy. Guttmann (1977) was the first to study the size and effect of tax evasion. He estimates the size of the underground economy or the subterranean economy as large as $9.4 \%$ of U.S. GNP, which caused a lot of attention to the issue of tax evasion. Also, he mentions that the underground economy is a product of government regulations and policies and suggest revising them in order to not motivate unreported activities. However, Feige (1979) estimates of the irregular economy were far bigger than Guttmann estimation. He finds that the size of the illegal economy is $22 \%$ of GNP in 1976 and $33 \%$ of GNP in 1978. His recommendation is to reduce tax rates in the legal sector, increase the punishment for participation in the illegal activities and also 
legalizing currently illegal activities such as gambling and use of marijuana. Clotfelter (1983) using the Internal Revenue Service's Taxpayer Compliance Measurement Program (TCMP) survey for 1969 finds that marginal tax rates affect the amount of tax evasion significantly. An alternative view finds no evidence regarding the positive relationship between tax rates and tax evasion (Friedman et al., 2000). They claim that businesses and people may be derived to the underground economy because of weak institutions which are responsible for protecting people's rights. According to this view, Weak jurisdictional system, bureaucracy and corruption are the primary reasons that lead people to underground and unreported economy.

Table 2: Effects of Income Tax Evasion on The Economy

\begin{tabular}{|c|c|c|c|c|c|}
\hline Impact & Category & Frequency & Percent & Mean & Std. Deviation \\
\hline \multirow{6}{*}{$\begin{array}{c}\text { Reduction } \\
\text { in Country's } \\
\text { economy growth }\end{array}$} & Strongly disagree & 0 & 0 & \multirow[b]{6}{*}{4.7} & \multirow[b]{6}{*}{0.535} \\
\hline & Disagree & 0 & 0 & & \\
\hline & $\begin{array}{l}\text { Neither agree nor } \\
\text { disagree neither }\end{array}$ & 1 & 3.3 & & \\
\hline & Agree & 7 & 23.3 & & \\
\hline & Strongly agree & 22 & 73.3 & & \\
\hline & Total & 30 & 100 & & \\
\hline \multirow{6}{*}{$\begin{array}{l}\text { Increase in } \\
\text { inflation }\end{array}$} & Strongly disagree & 0 & 0 & & \multirow[b]{6}{*}{0.535} \\
\hline & Disagree & 1 & 3.3 & & \\
\hline & $\begin{array}{l}\text { Neither agree nor } \\
\text { disagree neither }\end{array}$ & 12 & 40 & & \\
\hline & Agree & 13 & 43.3 & & \\
\hline & Strongly agree & 4 & 13.3 & & \\
\hline & Total & 30 & 100 & 2.7 & \\
\hline \multirow{6}{*}{ Impact on moral } & Strongly disagree & 1 & 3.3 & \multirow[b]{6}{*}{3.9} & \multirow[b]{6}{*}{0.868} \\
\hline & Disagree & 9 & 30 & & \\
\hline & $\begin{array}{l}\text { Neither agree nor } \\
\text { disagree neither }\end{array}$ & 11 & 36.7 & & \\
\hline & Agree & 9 & 30 & & \\
\hline & Strongly agree & 0 & 0 & & \\
\hline & Total & 30 & 100 & & \\
\hline
\end{tabular}




\begin{tabular}{|c|c|c|c|c|c|}
\hline \multirow{5}{*}{$\begin{array}{l}\text { Increase in } \\
\text { corruption }\end{array}$} & Strongly disagree & 0 & 0 & \multirow[b]{6}{*}{3.9} & \multirow[b]{6}{*}{0.868} \\
\hline & Disagree & 1 & 3.3 & & \\
\hline & $\begin{array}{l}\text { Neither agree nor } \\
\text { disagree neither }\end{array}$ & 8 & 26.7 & & \\
\hline & Agree & 13 & 43.3 & & \\
\hline & Strongly agree & 8 & 26.7 & & \\
\hline & Total & 30 & 100 & & \\
\hline \multirow{6}{*}{$\begin{array}{l}\text { Decrease in } \\
\text { country's } \\
\text { reputation }\end{array}$} & Strongly disagree & 0 & 0 & \multirow[b]{6}{*}{3.5} & \multirow[b]{6}{*}{0.63} \\
\hline & Disagree & 1 & 3.3 & & \\
\hline & $\begin{array}{l}\text { Neither agree nor } \\
\text { disagree neither }\end{array}$ & 14 & 46.7 & & \\
\hline & Agree & 14 & 46.7 & & \\
\hline & Strongly agree & 1 & 3.3 & & \\
\hline & Total & 30 & 100 & & \\
\hline
\end{tabular}

Source: Field survey, 2016

Table 2 shows the impact of Income tax evasion in Nepal given by the traders. Tax evasion and thereby establishment of parallel economy has been creating the following serious impacts on the social and economic system of the country. Most of the respondent agreed on the opinion that tax evasion has been causing reduction in country's economic growth (mean score 4.7) 96.6\%, Decrease in country's reputation (mean score 4.6), Impact on moral (mean score 3.9), Increase in corruption (mean score 3.9), Increase in inflation (mean score 2.7). Tax evasion has resulted in the diversion of resources for the purchase of real estate and luxury housing.

\section{Conclusion}

Developing countries face many kinds of problems and challenges in the colossal task of tax collection. First, developing countries have difficulties in identifying surpluses in the economy on account of their low GNP, low rate of capital formation, poverty, unemployment, higher population density, etc. Second, their chances of tax collection are further diminished on account of predominantly cash transactions with no trails, a huge black economy, and rampant tax evasion. Third, there is a lack of political will power to collect revenues that results in a narrow tax base on account of a number of politically motivated tax exemptions and deductions. Citizens and taxpayers in developing countries suffer in many ways.

First, there is less development because of a paucity of funds with the government and corruption among the people of higher rank. Second, with the predominance of regressive indirect taxes, the poorer section of society has to sacrifice a bigger share of income in taxes compared to richer persons of society. Further, taxpayers suffer greatly on account of absence of a fair dispute resolution system. 
To deal with this situation, governments of these countries must take steps to widen their tax base and to reduce the black economy, thereby reducing tax avoidance and tax evasion. In order to reduce the black economy and tax evasion, all citizens of these countries must be issued a universal identification number, much like the United States social security number, to keep track of their transactions. Currency of higher denominations must be withdrawn and income from all sources should be made taxable. The governments must show will power to collect taxes by withdrawing all popular and politically motivated exemptions.

Larger taxpayers and their tax avoidance motives need to be closely monitored. The officers of the tax department and other senior politicians and officials should have greater responsibility to higher standards of tax compliance. Codes and regulations must be simplified to permit better understanding and better tax compliance by taxpayers.

The study was to find out the problem connected with income tax evasion on the economy. The research revealed many problems on individuals' attitude towards income tax. It was found out that their educational background was low. This was especially in the case of traders. Most of them were basic and secondary school leavers who had no in-depth education in taxes. Also, it was observed that the traders did not keep proper records, which makes it difficult to ascertain their correct and actual assessable incomes. Again, the traders' taxes were used on public officials instead of using it for national development to the benefit of the tax payers and the nation at large, the traders claim. Other conclusions drawn from the study are as follows;

There is a poor customer relation on the part of the IRD officials. Income tax rate is very high; tax collectors seem to be willing to cheat to the tax payers. Thus, figures are understated for tax payers to pay low and the rest of the money which is supposed to be credited to the consolidated fund rather goes into individual income tax collector's pocket, most people do not know the importance of tax and therefore feel reluctant to come forward boldly to declare their incomes for tax purposes, tax education for traders is not sufficient.

\section{Recommendations}

Provided Universal Identification Number for all people, Government should strictly check on Real Estate Transfers, Banking channels those are used for cash transactions, Simplification and Transparency Based on Mutual Trust. Training for tax officials, Tax education for public, visit to self-employed place, fairly distribution of resources and tax education for youths should be done in order to get the solution. 


\section{References}

Akdede, S. H. (2006). 'Corruption and Tax Evasion'. Dorus Universities Dergisi, 2 (7), 141-149. https://doi. org/10.31671/dogus.2019.247

Allingham, M. G. and Sandmo, A. (1972). 'Income tax evasion: a theoretical analysis'. Journal of Public Economics 1:323-38. North-Holland.

Alm, J., McClelland, G. H. and Schulze, W. D. (1992). 'Why Do People Pay Taxes?' Journal of Public Economics, Vol. 48, pp. 21-38. USA.

Becker, G. S. (1968a). 'Crime and Punishment: An Economic Approach'. Journal of Political Economy, 76(2), 169-217. https://doi.org/10.1086/259394

Britannica Concise encyclopedia (2006). Encyclopedia Britannica, Inc. Printed in Peru.Company, Chicago, USA.

Dahal, M. K. (1995). Tax system review task forces Report, Ministry of Finance, HMG/Nepal.

Dahal, M. K.. (2006). 'A Landmark in the History of Reforms in Nepal's Tax System,' Telegraph Nepal, December 22.

Dahal, M. K. (2012). Nepalese Economy: Development vs. Underdevelopment.http://www.telegraphnepal. com/national/2012-10-08/nepalese-economy:-development-vsunderdevelopment.html, accessed by the authors on June 21, 2012.

Etzioni, A. (1986). 'Tax Evasion and Perceptions of Tax Fairness', A Research Note, The Journal of Applied Behavioral Sciences, 22(2), 177-185.

Fishburn, G. (1981). 'Tax Evasion and Inflation'. Australian Economic Papers 20:325-32.

Fisman, R., and Wei, S. (2003). Tax rates and Tax Evasion: Evidence from Missing Imports in China, Bureau for Research in Economic Analysis of Development (BREAD) Germany.

Innes, William I. (1987). Tax Evasion in Canada, Carswell: Toronto.

IRD. (2013). Income Tax, Kathmandu: In land Revenue Department.

Kandel, P. R. (2011). Tax Laws and Tax Planning in Nepal, Kathmandu: Benchmark Education Support Pvt.Ltd.

Khanal, M. (2016). “Income Tax Evasion and Its Effects on The Economy”, An unpublished M.phil degree thesis, submitted to Central Department of Economics, T.U., Kathmandu, Nepal

Levin, J. \& Widell, L. (2007). 'Tax Evasion in Kenya and Tanzania:Evidence from Missing Imports', Working Papers 2007:8, Örebro University, School of Business.

McGee, R. W. (2012). Education Level and the Ethics of Tax Evasion. Chapter 28, in R. USA

McGee, R. W. (1999). 'Why People Evade Taxes in Armenia. A Look at an Ethical Issue Based on a Summary of Interviews', Journal of Accounting, Ethics \& Public Policy2(2): 408-416. Reprinted at http://ssrn.com/abstract=242568USA

MoF (2009). Economic survey, (Various Issues), Kathmandu: Singha Darbar.

MoF (2009-2010). Budget speech, (Various Issues), Kathmandu: Singha Darbar.

Murphy, R. (2011). The Cost of Tax Abuse: A Briefing Paper on the Cost of Tax Evasion Worldwide. The Tax Justice Network,

Sandmo, A. (2005), The Theory of Tax Evasion: A Retrospective View, National Tax

Tanzi, V. (1998). Corruption Around the World: Causes, Consequences, Scope and Cures. IMF Staff Papers, Vol. 45, No.4, December, Retrieved May 4, 2008, http://www.jstor.org/pss/387585, pp. 559-594

Webley, P. et al. (1991). Tax Evasion. An Experimental Approach, Cambridge University Press, Cambridge and New York. 
Webley, P. (1991). Tax Evasion: An Experimental Approach. Cambridge. New York.

Wolf, H. K. and Pant, P. R. (2002). Social science research and thesis writing. Kathmandu: Buddha Academic Publishers and Distributors Pvt. Ltd.

Yitzhaki, S. (1974). Income tax evasion: A theoretical analysis. Journal of Public Economics, 3(2), 201202. https://doi.org/10.1016/0047-2727(74)90037-1

\section{Websites}

Retrieved from http:/www.telegraphnepal.com/national/2012-10-08/nepalese-economy:-developmentvsunderdevelopment. html, accessed by the authors on June 21, 2012.

Retrieved from http://www.ird.gov.np/information.php? c=Income Percent 20 Tax, accessed on May 23, 2013.

Retrieved from http://www.ird.gov.np/information.php? c=Income Percent 20Tax, accessed on May 23, 2013.

Retrieved from http://www.imf.org

Retrieved from http://www.ird.gov.np

Retrieved from http://www.nepalchamber.org/policies/incometax.php

Retrieved from http://www.trunco.com.np/pdf/Budget_Highlights_2014-15.pdf

Retrieved from http://www.allbankingsolutions.com/Personal-Finance/Latest-Income-Tax-Slabs-Rates. htm

Retrieved from http://www.pwc.com/gx/en/tax/corporate-tax/worldwide-tax- summaries/ assets/pwcworldwide-tax-summaries-corporate-2014-15.pdf

Retrieved from http://www.scopulus.co.uk/taxsheets/usa_taxrates_2014.htm

Retrieved from http://www.lameta.univ-montp1.fr/Documents/DR2009-01.pdf

Retrieved from http://www.tackletaxhavens.com/Cost_of_Tax_Abuse_ TJN Percent 20Researc_23rd Nov_2011.pdf

Retrieved from http://www.davemanuel.com /investor-dictionary/tax-evasion/

Retrieved from http://dl.yazdanpress.ir/BOOKS/HISTORY\%20AND Percent 20 GEOGRAPHY /A World_History_of_Tax_Rebellions(marked).pdf 